\title{
Die relevansie van die boek Prediker
}

\author{
WC van Wyk (jr) \\ Randse Afrikaanse Universiteit
}

\begin{abstract}
The relevance of the book of Ecclesiastes
\end{abstract}

Since the book of Ecclesiastes is generally neglected in biblical theology, systematic theology and the preaching of the church, the question is asked whether it is still relevant for the church. After a cursory look at some prominent ideas in the book, the relation between Ecclesiastes and the rest of the Bible is investigated, and a number of comparisons between Ecclesiastes and modern thinkers are considered. Finally an attempt is made at evaluating the relevance of the book of Ecclesiastes and indicating ways in which it might be explored for the theology and preaching of the church.

\section{INLEIDING}

Die relevansie van 'n Bybelboek kan bepaal word deur die belang daarvan vir die wetenskaplike beoefening van die teologie en vir die verkondiging van die kerk te ondersoek.

Dit is welbekend dat die wysheidsliteratuur in die verlede altyd die stiefkind van die Ou-Testamentiese teologie was. So toon Scobie byvoorbeeld statisties aan hoe min aandag wysheidsliteratuur in werke oor die teologie van die Ou Testament kry: van minder as een persent in die werke van Köhler en Vriezen tot 'n maksimum van 11,5\% in die werk van Zimmerli (1984: 43-44). Dit hoef niemand dus te verbaas dat hierdie verwaarlosing van onder andere die boek Prediker in 'n Bybelse teologie ook in die dogmatiek te bespeur is nie. 'n Vinnige oorsig oor die teksverwysings van 'n paar wydgelese dogmatiekhandboeke kan dit bevestig. In Karl Barth se omvangryke Kirchliche Dogmatik word Prediker slegs vyf en dertig maal aangehaal en slegs sewe maal word teksgedeeltes bespreek. Emil Brunner haal Prediker glad nie aan nie, en Otto Weber slegs drie keer. Dit is interessant dat hierdie verwaarlosing van Prediker ook in 'n meer moderne werk soos $\mathrm{H}$ Berkhof se Christelijk geloof opgemerk kan word. Die enigste moontlike gevolgtrekking is dat die dogmatici wat 'n 
eietydse uiteensetting van die geloof moet gee, die relevansie van die boek Prediker nie baie hoog ag nie.

Dieselfde is waarskynlik ook waar van die verkondiging van die kerk. Hoe dikwels preek predikante uit Prediker? Ook uit die kerk se verkondiging blyk 'n verleentheid met hierdie boek.

In die lig hiervan is die volgende stelling van Whybray (1980: 3) opvallend:

\begin{abstract}
Among the books of the Old Testament there are perhaps only two which the present-day reader might be disposed to call 'modern'. By this I mean that anyone reading them for the first time would be able to come to terms with them as serious discussions of real problems problems recognizably the same as those which still puzzle modern men, and treated in a way sufficiently close to modern theological or philosophical discourse to make unnecessary the performance of those mental contortions and cultural gymnastics which are usually necessary before a modern reader can enter into the world of what we are accustomed to call 'pre-logical' or 'proto-logical' thought.... These two exceptional works within the literature of the Old Testament are the books of Job and Qoheleth.
\end{abstract}

Om nou die relevansie van die boek Prediker te probeer bepaal, wil ek agtereenvolgens aandag gee aan die inhoud van die boek, die verband tussen Prediker en die res van die Bybel, en raakpunte tussen Prediker en sekere moderne denkrigtings.

\title{
2. DIE INHOUD VAN DIE BOEK PREDIKER
}

\subsection{Opbou van die boek}

'n Goed gestruktureerde teks - van watter omvang ook al - vergemaklik altyd die leser se taak om die gedagtegang daarvan te volg en die inhoud daarvan te verstaan.

Dit is waarskynlik een van die eerste probleme waarmee 'n leser van die boek Prediker te doen kry: vandaar die verskillende sienings oor die opbou en inhoud van die boek. Verskeie geleerdes het met pogings vorendag gekom om die struktuur van die boek Prediker bloot te lê, maar met totaal uiteenlopende resultate (kyk veral Zimmerli 1974 en Crenshaw 1988 vir oorsigte).

Die uiteenlopende resultate waartoe verskillende geleerdes kom, hou onder andere ook verband met hulle uiteenlopende sienings oor die eenheid of integriteit van die boek. Hier speel geleerdes se subjektiewe voorkeure dikwels 'n bepalende 
rol wanneer hulle sekere gedeeltes van die teks eenvoudig elimineer om 'n struktuur in die boek bloot te lê. Terwyl die refreine 'Alles kom tot niks' en 'Wat kry die mens vir sy geswoeg?' deur baie beskou word as die sentrale gedagtes van die boek, is Rousseau (1981: 216) byvoorbeeld van mening dat dit waarskynlik beskou kan word as die resultaat van latere redaksionele bewerkings!

Hoewel dit seker nie betwis kan word dat daar latere redaksionele toevoe-gings in die huidige vorm van die teks opgeneem is nie, is dit gewoonlik baie moeilik om die werk van ('n) redaktor(e) met 'n hoë mate van sekerheid aan te dui, en is daar dikwels groot meningsverskil hieroor tussen verskillende geleerdes. Verder moet onthou word dat dit by die interpretasie van die Bybel uiteindelik gaan om die verstaan van die finale fase van kanonisering of die huidige vorm van die teks. Indien daar dus gepoog word om die struktuur van 'n teks aan te dui, dan moet dit die struktuur van hierdie laaste fase wees - dit wil sê die teks met insluiting van redaksionele byvoegings.

Wanneer die opbou van die boek bespreek word, moet daar aandag geskenk word aan die eenheid van vorm en inhoud in die boek. Die eerste formele saak wat opval is dat prosa en poësie afwisselend voorkom sonder dat daar ' $n$ vaste patroon of reëlmaat te bespeur is. Verder kontrasteer die gebruik van die eerste persoon in baie gedeeltes (bv die koningsfiksie in 1: 12-2: 26 en die gedeeltes waarin ' $n$ persoonlike belewenis of cordeel weergegee word) met die onpersoonlike gebruik van die derde persoon in ander (bv 4: 9-12 en 7: 1-8), en die vermanings wat direk aan die tweede persoon gerig is (bv 4: 17-5: 6). Verskeie gedeeltes in die boek (bv 9: 17-10: 20) vertoon duidelike formele ooreenkomste met die versamelings losstaande spreuke wat tipies is van die ouer spreukwysheid. Daarteenoor vind ons egter weer ander gedeeltes waar 'n vraagstelling langer volgehou word - indien nie deur 'n reglynig ontwikkelende gedagtegang nie, dan wel deur assosiasie (vgl 1: 12-2: 11 en 6: 10-7: 14 ; so Zimmerli 1974).

Die herhaling van frases soos 'Alles kom tot niks', 'Dis 'n gejaag na wind', en 'Wat kry die mens vir sy geswoeg?' versterk die indruk van eenheid in die boek, maar omdat dit nie volgens ' $n$ vaste patroon voorkom nie, is dit nie moontlik om op grond daarvan 'n duidelike struktuur in die boek aan te toon nie. Die inhoud van die boek vertoon nie slegs een tema ('Alles kom tot niks') wat logies en sistematies beredeneer word nie, maar bevat ook ander gedagtes (soos die oproep tot vreugde, die vermaning om God te dien en die erkenning van die relatiewe voordeel van die wysheid) waarvan die verband met die dominerende frase omstrede is. Die eenheid van die boek word eerder versterk deur die herhaling van verskillende gedagtes en woorde (vgl Crenshaw 1988: 36). 
Loader (1979) het die prominente rol wat polère strukture formeel en inhoudelik in Prediker speel oortuigend aangetoon (volgens hom is dit aanwesig in elke gedeelte van die boek behalwe 1: 2-11 en 7: 8-10). Daar moet egter onthou word dat inhoudelike polariteite nie noodwendig impliseer dat 'n perikoop formeel ook poler gestruktureer moet wees of dat verskillende perikope in die boek (ook oor dieselfde onderwerp) dieselfde opbou vertoon nie. Wat egter duidelik blyk dat ook Loader se insigte nie 'n omvattende makrostruktuur in die boek (kan of wil) blootle nie, is sy erkenning dat daar nie altyd 'n voortgaande logiese ontwikkeling binne 'n groep perikope aan te wys is nie (Loader 1979: 113). Hy wys ook daarop dat nie alle perikope tematies verband hou met die perikope waartussen hulle geplaas is nie. Waar Loader wel 'n aantal perikope saamgroepeer (bv 3: 1-9; 3: 10-15; 3: 16-22; 4: 1-3; 4: 4-6; 4: 7-12 en 4: 13-16) kan daar bowendien nog gevra word of dit nie slegs moont-lik gemaak word deur die vae en algemene opskrifte wat aan die perikope gegee word nie. Is 'The inhuman human' (1979: 93) byvoorbeeld die akkuraatste opskrif vir 3: 16-22 en 4: 1-3? Is daar nie ander perikope wat inhoudelik nader verband hou met hierdie twee gedeeltes nie?

Dit is te betwyfel of daar ooit 'n omvattende stuktuur in die boek aangedui sal kan word (so ook Murphy 1955: 306 en Crenshaw 1988: 47). Alhoewel die boek Prediker nie sonder enige struktuur of eenheid is nie, kan daar tog geen volgehoue logiese of formele strukturering aangetoon word wat ' $n$ vaste gids kan wees by die interpretasie van die inhoud nie. Dit sal beter wees om na belangrike, herhalende gedagtes in die boek te kyk om so 'n idee te vorm van die inhoud en boodskap van die boek.

\subsection{Hooftrekke}

Om reg te laat geskied aan die uiteenlopende stof in hierdie vreemde boek is geen maklike taak nie. Dit hoef niemand dus te verbaas dat daar in die verlede soveel teenstrydige beoordelings van Prediker gemaak is nie - van 'n opperste pessimis tot 'n prediker van vreugde. Aangesien die inhoud van die boek hier uiteraard nie volledig bespreek kan word nie, word daar nou slegs 'n bondige oorsig gegee van enkele prominente gedagtes in die boek.

Eerstens is daar die frase wat 'n raam om die boek vorm (1:2 en 12:8) en in verskillende vorms regdeur die boek voorkom. Hierdie frase wil die Hebreeuse woord kom tot niks'. Díe negatiewe oordeel word uitgespreek oor die lewe in die algemeen en ook oor verskeie spesifieke sake. Niks gee aan die lewe sin nie: nie dwaasheid, die plesiere van die lewe, rykdom, besittings of wyn nie. Ook groot ondernemings, drome, jeugdigheid en selfs die strewe na wysheid en kennis het geen 
blywende waarde nie. In hierdie verband is dit interessant om daarop te let hoe dikwels die woord vraag gestel: 'Wat kry die mens vir sy geswoeg, sy geswoeg in die wêreld?' Telkens herhaal Prediker sy standpunt dat harde werk 'n tevergeefse geswoeg is wat geen blywende voordeel inhou nie. Menslike pogings om die lewe suksesvol te beheers, word verskeie male ook beskryf as 'n gejaag na wind.

Prediker teken hierdie swartgallige prentjie van die lewe omdat hy sien dat verkeerde dade nie meteens gestraf word nie, en goeie dade ook nie beloon word nie. Dieselfde lot tref almal - mens en dier, wyse en dwase, regverdige en goddelose. Die voordeel wat 'n mens wel in die lewe kan behaal, word uitgewis deur die onvermydelike dood. Die finaliteit van die dood wat alle verskille tussen mense uitwis, speel 'n baie groot rol in al Prediker se denke en soeke na sin in die lewe. Boonop word niemand ná sy dood onthou nie.

Tog moet die aandag ook gevestig word op ' $n$ heel besondere refrein, naamlik die oproep om die lewe te geniet, wat sewe keer in die boek voorkom (2: 24-26; 3 : 12-13; 3: 22; 5: 17-19; 8: 15; 9: 7-10 en 11: 7-10). Hoewel Rousseau (1981) waarskynlik te ver gaan om hierin 'n duidelike struktuurmerker te sien, het hy tog oortuigend aangetoon dat hierdie positiewe oproep nie eenvoudig as 'n later redaksionele toevoeging uit die teks geskrap kan word nie. In hierdie refrein is daar vyf elemente wat met verbasende reëlmaat voorkom: 'n element wat die aandag trek, 'n waarde-oordeel, ' $n$ uitnodiging tot vreugde, 'n verwysing na die werk van die mens en laastens ' $n$ vermelding van hierdie vreugde as 'n gawe van God. Whybray (1982) het ook aandag gegee aan hierdie refrein (al is dit by hom effens anders afgebaken) en kom tot die gevolgtrekking dat dit 'n soort Leitmotiv is wat algaande al meer klem in die boek ontvang.

Hoe Prediker se oproepe om die lewe te geniet in verband gebring moet word met sy sinloosheidsuitsprake, is 'n moeilike en omstrede saak. Dit sal egter eensydig wees om Prediker se oproepe tot lewensvreugde bloot te sien as iets wat sy negatiewe uitsprake oor die lewe op ' $n$ ironiese wyse bevestig en aksentueer. S6 'n standpunt moet die noukeurige opbou van hierdie unieke refrein wat by herhaling voorkom, as onbenullig afmaak sonder om erns te maak met die betekenis wat dit binne die konteks kan hê. Net so kan hierdie refrein ook nie gebruik word om Prediker voor te stel as iemand wat homself uiteindelik tog volkome dankbaar en tevrede voor sy Lotsbeskikker stel nie. Müller (1986: 11) wys daarop dat Prediker in hierdie gedeeltes telkens die relatiewe voordeel van lewensvreugde aantoon teen die agtergrond van sy bewussyn van die dood. Uit die konteks van hierdie gedeeltes is dit duidelik dat dieselfde dinge wat Prediker se lewensvreugde bedreig, dit tog ook weer vir hom moontlik maak om bepaalde dinge as gawes uit die hand van God 
te geniet. Juis die feit dat hy insien dat 'n mens se lewe kort is, dat 'n mens nie sy eie lot of voorspoed kan bepaal nie, dat 'n mens nie weet wat die toekoms vir hom inhou nie en dat ' $n$ mens nie die lewe kan verstaan nie, bring hom daartoe om sy lesers aan te spoor om die geleenthede wat God hulle in hulle lewens bied, aan te gryp as 'n gawe uit die hand van God.

Sewe keer roep Prediker sy lesers op om ontsag te hê vir God (3: 14; 5: 6; 7: 18; 8: 12; 8: 13 en 12: 13). Vroeër is hierdie tekste veral op literarkritische gronde as latere toevoegings uit die teks geskrap, maar dit kan vandag nie meer aanvaar word nie (vgl Pfeiffer 1965). Hierdie oproep om ontsag te hê vir God bly nogtans merkwaardig, veral in die lig van Prediker se onvermoë om God se optrede te begryp. Prediker is egter geen ateïs nie; hy verstaan net nie God se optrede in die wereld nie. So sê Zimmerli (1983: 110): 'Gott selber fallt in all der Rätselhaftigkeit seines Tuns ... nie unter das Verdikt der Nichtichkeit.' Prediker voel homself magteloos en kwesbaar voor die magtige, soewereine God. Sy raad dat mense moet ontsag hé vir God spruit juis uit sy besef van sy eie nietigheid en sy belewenis van die afstand tussen homself en God. Maar dan glo Prediker aan die ander kant nog steeds nie dat die regte ontsag vir God alle probleme en teenstrydighede uit die aardse lewe elimineer nie (vgl 8: 11-14).

Uit hierdie oorsig van enkele belangrike gedagtes in Prediker is dit dus duidelik dat Prediker die lewe nie (soos dikwels geglo word) net eensydig negatief beoordeel nie, maar dat hy 'n pragmatiese persoon is by wie daar tog ook - hoewel gekwalifiseerd - 'n positiewe benadering teenoor die lewe bestaan. Indien te veel klem op Prediker se nietigheidsuitsprake gele word, moet sy oproep om die lewe te geniet, sy vermaning om ontsag te hê vir God, asook sy erkenning van die relatiewe voordeel van die wysheid en sy raad oor die verdeling van risiko's, of as redaksionele toevoegings geëlimineer word df afgemaak word as elemente van die tradisionele wysheid waarteen gepolemiseer word. Indien al hierdie dinge egter gesien word in die lig van Prediker se besef van die mens se onmag voor sy Lots-beskikker, sien ons 'n praktiese mens wat weliswaar nie volkome tevrede is met die werklikheid waarin hy hom bevind nie, maar desondanks nie in totale wanhoop ver-val nie.

\section{DIE VERBAND TUSSEN PREDIKER EN DIE RES VAN DIE BYBEL}

\subsection{Die wysheidsliteratuur in die Ou Testament}

Aangesien Prediker gewoonlik saam met Spreuke en Job tot die korpus van die OuTestamentiese wysheidsliteratuur gereken word, moet daar eerstens aan hierdie onderlinge verband aandag geskenk word. 
Daar is verskeie formele en inhoudelike ooreenkomste. Net soos die ander wysheidsliteratuur maak Prediker ook gebruik van spreuke (Murphy 1981: 4 onderskei tussen proverbs, experiential sayings en didactic sayings), bevele, verbiedinge, diskussies en intellektuele besinnings. En net soos die ander wysheidsliteratuur worstel Prediker ook met die mens se pogings om die lewe te bemeester, met die probleem van lyding, met die grens wat die dood aan die lewe stel, en met die soeke na die waarheid. Dis belangrik om raak te sien dat Prediker, net soos Spreuke en Job, veronderstel dat God die almagtige Skepper is wat die lot van mense in sy hand hou.

Tog verskil Prediker skerp van die sterk kousale verband wat in die vroeëre wysheidsliteratuur gele is tussen 'n mens se dade, die gevolge daarvan en die aansien wat hy in die samelewing geniet. Vir hom is heil nie iets wat 'n mens self kan bewerkstellig nie; dit is altyd bloot 'n gawe van God. Hierdie standpunt is die gevolg van sy volgehoue kritiese waarnemings van die werklikheid: dit gaan nie altyd goed met regverdiges nie, en dit gaan ook nie altyd sleg met goddeloses nie. Hy sien $60 \mathrm{k}$ raak dat regverdiges teenspoed beleef en goddeloses voorspoed. Hy is nie bereid om sulke uitsonderings op die tradisionele siening te ignoreer of as onbenullig af te maak nie, maar dring konsekwent aan op die verifikasie wat die werklikheid kan bied.

Die gevolg van hierdie siening van Prediker is dat hy enige poging om God se guns te wen as tevergeefs en as 'n gejaag na wind beskou. Dit kontrasteer met die Spreukeboek wat mense aanspoor om vroom te lewe en vas te hou aan die wysheid van vorige geslagte, aangesien hulle God so kan beweeg om aan hulle voorspoed te skenk.

Die tradisionele wysheidsliteratuur het daarop aanspraak gemaak dat dit die orde waaraan die lewe en werklikheid onderwerp is, kan verstaan en dus op grond daarvan weet hoe om die meeste voordeel vir die mens te bewerk. Tog verwerp Prediker ook hierdie aanspraak: die mens is nie in staat om te verstaan wat in hierdie wêreld gebeur nie (8: 16-17). Juis die mens se onvermoë om die werklikheid te begryp, bring hom daartoe om ontsag vir God te hê (3: 14).

In die lig van hierdie verskille tussen Prediker en die vroeère wysheidsliteratuur (soos dit veral in Spreuke en in die standpunte van Job se vriende na vore kom), is die gevolgtrekking noodwendig dat Prediker in reaksie kom teen tradisionele standpunte. Teenoor die tradisionele sienings beklemtoon Prediker die onvoorspelbaarheid van die lewe en die mens se onvermoē om daaroor beheer uit te oefen. Só dien Prediker binne die wysheidsliteratuur as 'n kritiese waarskuwing om nie te verval in 'n simplistiese of eensydige siening van die lewe nie. Dit is egter belangrik om raak te sien dat Prediker se siening van die wysheid nie eensydig 
negatief is nie. Dat wysheid ook voordeel inhou, blyk duidelik uit gedeeltes soos 7 : 11-12, 19 en 8: $1,5$.

\subsection{Die res van die Ou Testament}

Die probleem van die verband tussen die wysheidsliteratuur en die res van die Ou Testament is reeds lankal bekend. Die kenmerkende idees van die res van die Ou Testament is vreemd aan die wysheidsliteratuur: uitverkiesing, verbond, Israel as volk voor God, God se selfopenbaring deur sy heilsdade in die volksgeskiedenis ensovoorts.

Ook Prediker verskil in hierdie opsig van die hoofstroom van die Ou-Testamentiese tradisies. Trouens, Prediker gebruik nooit die woord i? 'י 'n naam vir God nie en verwys ook nie na sy volk se tradisies van God se openbaring in hulle geskiedenis nie.

Tog moet daar nie net 'n eensydige klem gelê word op die verskille tussen die wysheidsliteratuur en die res van die Ou Testament nie, maar moet die raak-punte en ooreenkomste ook raakgesien word. So deel Prediker (en die wysheidsliteratuur oor die algemeen) hulle belangstelling in die lot van die regverdige en die goddelose met die res van die Ou Testament, al ontvang hierdie tema daar nie soveel klem nie en word dit vanuit 'n ander hoek benader.

En ten spyte van al die verskille, praat Prediker nog steeds van dieselfde God en glo hy, net soos die res van die Ou Testament, dat hierdie God die lot van mense bepaal. Die wysheidsliteratuur (en dus ook Prediker) het immers nie in 'n godsdienstige vakuum ontstaan nie, maar in die midde van die Godsvolk, Israel, en binne die konteks van hulle godsdienstige tradisies. Die blote feit dat die wysheidsliteratuur saam met die res van die Ou Testament as kanon oorgelewer is, bewys dat daar vir Israel van ouds geen teenstelling bestaan het nie, maar dat daar binne een breê tradisie ruimte was vir verskeidenheid.

\subsection{Die Nuwe Testanient}

Volgens die United Bible Societies se teks van die Nuwe Testament word Prediker ses keer in die Nuwe Testament aangehaal: in Romeine 8: 20 (Pred 1: 2), 1 Timoteus 6: 7 (Pred 5: 15), Jakobus 1: 19 (Pred 7: 9), Romeine 3: 10-12 (Pred 7: 20), Johannes 3: 8 (Pred 11: 5) en 2 Korintiërs 5: 10 (Pred 12: 14). Nie een van hierdie gevalle is egter ondubbelsinnig woordelikse aanhalings uit Prediker nie (so ook Oberholzer 1972: 5), maar eerder tematiese heropnames van gedagtes wat (ook) in Prediker voorkom. Die verband tussen Prediker en die Nuwe Testament sal dus 
eerder bepaal moet word deur te kyk na hoe bepaalde belangrike temas daarin hanteer word.

Die grootste verskil tussen Prediker en die Nuwe Testament is waarskynlik hulle onderskeie sienings oor die lewe en die dood. Prediker se onvergenoegdheid met die lewe is gegrond op sy onvermoë om die sin van die lewe in te sien, die onreg en smart wat hy in die lewe raaksien, en die dood se finale vernietiging van geleenthede om vreugde en sin in die lewe te vind. Die moontlikheid van 'n lewe na die dood word in Prediker 3: 19-21 geopper, maar afgewys. Sonder om op die diversiteit binne die Nuwe Testament in te gaan, is dit tog duidelik dat die sin en kwaliteit van die lewe daar deurgaans in 'n ander lig gesien word. Die Christusgebeure het nuwe sin in die menslike bestaan gebring, en die kwaliteit van lewe word nie meer bepaal deur die mate van voorspoed wat 'n mens beleef nie, maar deur die nuwe verhouding tussen God en mens. Hoewel daar in die Nuwe-Testamentiese geskrifte verskillende eskatologiese verwagtings leef, is dit duidelik dat die dood nie meer gesien word as vreesaanjaend en finaal nie. Sowel die verwagting van 'n spoedige wederkoms as die siening van 'n gerealiseerde eskatologie veronderstel dat Christus se opstanding aan gelowiges nuwe lewe gee ten spyte van die dood.

Nog 'n belangrike verskil tussen Prediker en die Nuwe Testament is die manier waarop die verhouding tussen God en mens beleef word. Vir Prediker is God ver van die mens verwyder, ver bo hom verhewe, onverstaanbaar en sonder medelye. Hierteenoor het Jesus Christus volgens die Nuwe Testament die afstand tussen God en die mense oorbrug, Hy het na die mense gekom en self mens geword. Die magtige God van hemel en aarde het nou in Jesus 'God by ons' geword; deur geloof in Jesus Christus word mense God se kinders (1 Joh 5: 1). God se besorgdheid oor die tydelike en ewige lot van mense word op verskillende maniere telkens deur die Nuwe-Testamentiese geskrifte aangetoon.

Die verreikende implikasies van God se nuwe openbaring in Jesus Christus is duidelik. Vanselfsprekend moet die Christelike kerk se teologie en prediking bepaal word deur die Nuwe-Testamentiese boodskap van die versoening en verlossing in Jesus Christus. Tog beteken dit nie dat Prediker (of die res van die Ou Testament) nou onwaar of waardeloos geword het nie. Prediker se uitsprake is gebaseer op sy kennis en ervaring van God in heel ander omstandighede as die van die Nuwe Testament. Prediker en die Nuwe Testament bely dieselfde God wat die lot van mense en die ganse heelal bepaal. Uit die onpersoonlike verhouding tussen God en mens, die tevergeefse soeke na sin in die lewe, en die neerdrukkende bewustheid van die finaliteit van die dood wat ons so duidelik in Prediker sien, word 
dit juis duidelik hoe belangrik dit vir 'n moderne mens is om God ook in die gestalte van Jesus Christus te ken.

\section{PREDIKER EN DIE MODERNE TYD}

Prediker se oordeel dat die lewe sinloos en onbegryplik is, laat 'n mens onwillekeurig dink aan soveel mense in ons moderne tyd. Die tydsgees van die twintigste eeu, veral na twee wêreldoorloë, kan met reg beskryf word as een van neerslagtigheid. Baie mense kon nie verstaan hoe God soveel ellende kon toelaat nie. Baie mense het hulle hoop en ideale prysgegee. In die lig hiervan is 'n vergelyking van Prediker met enkele moderne denkers nie net interessant nie, maar ook van belang vir die relevansie van Prediker.

In 1984 het FW Nichols 'n artikel gepubliseer waarin hy Prediker vergelyk met Waiting for Godot, die drama van die Frans-lerse skrywer Samuel Beckett. Nichols vind ooreenstemming tussen hulle in die feit dat die alledaagse lewe nie vir hulle veel sin maak nie. Dit is moeilik om te bewys dat daar 'n (Goddelike) plan is wat die geskiedenis bepaal, en tog behou beide 'n bepaalde verwagting en hoop. Alhoewel dit nie by een van die twee doelbewus en eksplisiet gesê word nie, is Nichols daarvan oortuig dat albei van hulle 'n dimensie van geloof belig: geloof is 'n stap verder as die rede, 'n daad van vertroue. Hy sluit soos volg af:

The fact that a frank recognition of this experience is part of the biblical canon is a great reassurance to contemporary believers. Each can say, 'I am not alone in feeling this insecurity.' Conversely, it is also something of a consolation to see the experience of hope, however bleak, in a writer like Beckett (Nichols 1984: 21).

Peter (1980) vergelyk Prediker met die denke van Albert Camus en kom tot die gevolgtrekking dat hulle albei besorg is oor die bestaan (eksistensie) van die mens. Hierdie besorgdheid oor die bestaan van die mens toon ooreenkomste in drie opsigte: beide vind die lewe eentonig en sonder voordeel of betekenis, beide staan gematigdheid voor, en beide wil die mens bevry van díe dinge wat die lewe sinloos maak. Die groot verskil tussen hulle is egter Prediker se geloof in God. Prediker wil God se geregtigheid in die lewe probeer verstaan, maar Camus glo nie in die bestaan van God nie en praat gevolglik nie eens van Hom nie. Dit is opmerklik dat die verbande wat Peter le tussen Prediker en Camus, baie algemeen is en rondom 'n sekere visie van die werklikheid sentreer, terwyl die verskil tussen hulle (geloof in God) in vele opsigte van kardinale belang is. 
Die waarde van 'n vergelyking tussen Prediker en die twintigste-eeuse eksistensialisme blyk duidelik uit die werk van Gordis (1951: 112-121). Hy wys daarop dat die sogenaamde eksistensialisme nie ' $n$ homogene beweging is nie, en dat slegs Jean-Paul Sartre homself as 'n eksistensialis beskryf het. Mense wat deur Gordis as verteenwoordigers van hierdie denkrigting gereken word, is Kierke-gaard, Jaspers, Heidegger, Marcel en Sartre.

Soos Prediker verwerp die eksistensialiste die tradisionele sisteme om die lewe te verklaar en beheers as leweloos en buite voeling met die werklikheid - die mens se plek in die wêreld moet eerder bepaal word op grond van elke individu se belewenis van die werklikheid. Prediker protesteer teen die tradisionele wysheid se vertroue dat 'n mens God se seèn op sy lewe kan verseker deur reg te leef. Net so is die eksistensiefilosofie 'n reaksie op die gees van selfvertroue wat vroeër in die Idealisme geheers het. Die eksistensialiste glo nie meer dat die mens met sy rede die wêreld kan verstaan en beheers om sodoende voortgaande vooruitgang in die werreld te verseker nie. Soos Prediker egter nie alle waarde aan die wysheid ontse nie, so verwerp die eksistensialiste ook nie die menslike rede volkome nie - hulle sien almal net die irrasionele, die absurde en die onbeheerbare in die lewe met nuwe helderheid raak.

By sowel Prediker as die eksistensiefilosofie is daar protes teen veralge-mening en abstrakte teorieē. Soos Prediker prakties in die lewe ervaar dat die aanvaarde standpunte nie altyd water hou nie, so lé die eksistensialiste klem op die expérience vécue (De Vos 1975:285), dit wil sê op die konkrete, onmiddellike ervaring van die werklikheid wat elke individu het.

Sowel Prediker as die eksistensialiste fokus op die dood, mislukking en sinloosheid in die lewe. Die gedagte dat die mens nie sy doel bereik nie, dat hy terugslae beleef en misluk, is algemeen by die eksistensialiste. Die pessimistiese gees wat teoloë so dikwels by Prediker raaksien, is ook 'n kenmerk van die eksistensialisme - so verwys De Vos (1975: 286) byvoorbeeld na die walging wat die lewe by Sartre opwek (vgl Pred 2: 17).

Daar is egter ' $n$ fundamentele verskil tussen Prediker en die eksistensialisme: vir Prediker is ' $n$ wêreld sonder God ondenkbaar; die blote bestaan van die wêreld getuig van die Skepper wat soewerein oor alle mense heers (Pred 9: 1). Prediker se hele stryd om sin en orde in die lewe te vind is juis 'n stryd met God: hy ontken die bestaan van God nooit nie, maar worstel met God wat Hom op geen manier deur mense laat manipuleer nie. Hierdie basiese verskil lei tot teenoorstaande lewenshoudings: Prediker berus in die aanvaarding van God se onbegryplike oormag en beskou die vreugde in die lewe as God se gawe aan die mens, terwyl die eksistensialisme uiteindelik nie daarin slaag om aan hulle wanhoop te ontsnap nie. 
Nog 'n belangrike verskil tussen Prediker en die eksistensialisme is die groot klem wat laasgenoemde op die vryheid van die mens laat val. Die eksistensialisme beklemtoon dat die mens vry is om keuses te maak en dat hy juis so sy eie lot bepaal en mót bepaal. Slegs deur telkens oorspronklike beslissings te maak wat nie deur enige norme vooraf gedetermineer is nie, kan 'n mens sy bestaan eg en betekenisvol maak. Dit staan in skrille kontras tot Prediker se onvergenoegdheid met die mens se onvermoë om sy lot op enige wyse tot sy eie voordeel te beïnvloed (vgl bv 3: 14).

Dat daar 'n wesenlike verskil is tussen Prediker en die eksistensialisme, blyk duidelik uit die verskillende lewenswyses wat hulle propageer. Al is Prediker ontevrede oor die skynbaar arbitrêre wyse waarop God sy wil in die wêreld laat geld, wys hy steeds op die mens se verantwoordelikheid voor God: God sal van die mens rekenskap eis (Pred 5: 5; 11: 9). Die eksistensialisme daarenteen beskou enige optrede volgens sedelike of godsdienstige norme as prysgawe van die mens se vryheid en verantwoordelikheid.

Ten spyte van oppervlakkige ooreenkomste, veral wat hulle waardering van die werklikheid betref, verskil die slotsom waartoe Prediker en hierdie moderne denkers kom, dus hemelsbreed.

\section{DIE RELEVANSIE VAN DIE BOEK PREDIKER}

\subsection{Vir die teologie}

Die verskille tussen die wysheidsliteratuur en die res van die Ou Testament toon aan dat die inhoud van die Ou Testament nie met behulp van 'n enkele tema of gesigspunt georden en weergegee kan word nie. Dit was die groot tekortkoming in verskeie van die belangwekkende teologieë van die Ou Testament wat die afgelope eeu verskyn het. So kan die hele Ou Testament byvoorbeeld nie gesien word as 'God se openbaring in die geskiedenis' of die 'verbondsverhouding tussen God en volk' nie.

Die eiesoortigheid van Prediker binne die Ou Testament dien as waarsku-wing dat die Ou-Testamentiese (en so ook al die Bybelse) materiaal nie eenvoudig onkrities op die moderne situasie toegepas kan word nie. Die Ou Testament en die Bybel reflekteer verskillende historiese situasies en gesigspunte. So kon Prediker byvoorbeeld nie meer die oortuiging onderskryf dat 'n goeie lewe voorspoed verseker nie. Die struktuur van die samelewing wat in verskillende tekste veronderstel word, is nie dieselfde nie. Die toepassing van Bybelse materiaal binne ' $n$ moderne teologie moet dus ook rekening hou met die veranderde situasie waarin ons leef. 
Roland Murphy (1982) gee 'n oorsig oor die interpretasie van Prediker in die geskiedenis. Daarin toon hy aan hoe die angel byvoorbeeld uit Prediker se stellings gehaal is deur die boek te sien as ' $n$ debat tussen Salomo en kwaadwillige dwase. Op grond daarvan is 9: 1-3 al beskryf as die 'gedagtes en misleidings en voorwendsels van dwase'. So 'n eensydige eliminasie van Bybelse materiaal kan nie vandag meer aanvaar word nie. Eweneens wys Salters (1975: 342) daarop dat die feit dat Prediker in die kanon staan, ons nie moet weerhou daarvan om sy skeptisisme raak te sien nie. Ook daarvoor moet ons op een of ander wyse ruimte laat in ons teologie.

Die groot verskille wat aangedui is tussen Prediker en die Nuwe Testament impliseer dat daar in 'n Christelike teologie nuwe antwoorde gegee sal moet word op Prediker se vrae na die sin van die lewe. Tog moet daar ruimte gelaat word vir die soort van kritiese lewensvrae wat Piediker stel. Daar is vandag (twee duisend jaar ná Christus) nog steeds baie mense wat die lewe as onregverdig en God as ver verwyder beleef, en wat dit moeilik vind om 'n lewende verhouding te hê met Gơ wie se teenwoordigheid in die wêreld selde tasbaar is. Alhoewel Jesus Christus aan moderne gelowiges nuwe hoop en 'n nuwe verhouding met God bied, moet die teologie ruimte laat vir mense se belewenis van wanhopigheid. Die verhouding tussen God en mens is nie altyd so eenvoudig as wat dit dikwels voorgehou word nie. Walsh (1982: 48) konkludeer: 'By offering scriptural precedent, no matter how anomalous, for the experience of hopelessness, Qoheleth becomes ironically, a sign of hope.'

Die moderne wêreld se uitsigloosheid bevestig die behoefte aan hoop. Deur in die eietydse dogmatiek aan Prediker 'n ernstige spreekbeurt te gee, kan die teologie 'n simpatieke aanknopingspunt vind vir sy gesprek met die wêreld. Prediker se donker prentjie van die werklikheid toon betekenisvolle ooreenkomste met die moderne denke. Maar Prediker bly glo in God se bestaan, Prediker bly glo dat God die lotgevalle van mense bepaal, en daarom soek hy nie sy heil in beperkte menslike moontlikhede nie. Deur gebruik te maak van die ooreenkomste tussen Prediker en die moderne denke, kan twyfelende mense na die ware hoop gelei word wat in die Nuwe Testament aan 'n wêreld in nood gebied word: Jesus Christus.

Tog moet ons perspektief behou: Prediker kan nooit die sentrum van 'n teologie word nie - daarvoor is sy waarnemings nie konsekwent genoeg beredeneer nie. Prediker identifiseer probleme in die tradisionele siening van die werklikheid en gee raad, maar bied geen finaal aanvaarbare oplossing nie. Zimmerli (1983: 113) stel die teologiese rol van Prediker besonder treffend: 
Gesamtbiblisch ist hier die Frage zu stellen, ob darüber - was dann im vollen Bekenntnis zu ... Gott ... zum Ausdruck kommt - recht geredet werden kann unter Überhören dessen, was der radikale Beobachter der Wirklichkeit der Gottbestimmten Welt in extremer Schärfe und Einseitigkeit allein einzuhämmern wagt: Gott ist Gott! Dass Gott redet, in seinen Dienst ruft, führt zu schwärmerischem Missverstehen, wenn nicht dieses Wissen allezeit gegenwärtig bleibt.

\section{En verder:}

Das Buch Kohelet bleibt in all der Einseitigkeit seines Redens ein unabdingbarer Wächter am Rande des biblischen Schrifttums (Zimmerli 1983: 114).

\subsection{Vir die kerk se verkondiging}

Vir 'n gelukkige, suksesvolle mens en 'n geordende, voorspoedige gemeenskap is die boodskap van Prediker seker nie altyd ewe aktueel nie. Maar wanneer teenspoed die lewe leeg en sinloos laat voorkom, bied Prediker die troos van kameraadskap (Walsh 1982:46)

Die waarde van die boek vir die verkondiging van die kerk le tot 'n groot mate daarin dat dit die mense in 'n moderne samelewing wat ook begin twyfel aan tradisionele sienings, kan aanspreek. Moderne mense wat beînvloed word deur nuwe verklarings vir die wereld en die lewe van mense, kan in Prediker ' $n$ begrypende gespreksgenoot vind - en tog 'n gespreksgenoot wat hulle altyd wil herinner aan die mens se onvermoẽ om sy eie lot te bepaal. Ten spyte van 'n mens se tevergeefse pogings om die werklikheid ten volle te begryp, herinner Prediker die mens altyd daaraan dat God in die hemel is en die mens op die aarde (so Zimmerli 1983: 113 met verwysing na Pred 5: 1; kyk ook Pred 6: 10).

Die epiloog van die boek sluit af met 'n vermaning dat God sal rekenskap eis van alies wat mense doen. Hierdie gedagte is egter nie net tot die epiloog beperk nie, maar kom ook in 3: 17 en 11: 9 voor. Ook die gedeeltes 4: 17-5: 6 en 11: 7-12: 8 impliseer dat die mens steeds teenoor God verantwoordelik bly vir sy dade. Dit is merkwaardig in die lig van Prediker se onvermoë om die werklikheid en God se rol daarin te begryp: uiteindelik besef ook hy dat die mens se lot in die hand van sy Skepper is.

Die kerk kan nie bekostig om die aanknopingspunt wat Prediker bied vir die 
prediking, die pastorale bearbeiding van soekende mense, en ook vir die sending en die evangelisasie, te ignoreer nie.

\section{Literatuurverwysings}

CRENSHAW, JL 1988. Ecclesiastes. London: SCM. (OTL)

DE VOS, H 1975. Inleiding tor de Wijsbegeente. 10de druk. Nijkerk: Callenbach.

GORDIS, R 1951. Koheleth - the man and his world New York: Schocken Books.

LOADER, JA 1979. Polar structures in the book of Qohelet. Berlin: De Gruyter. (BZAW.)

LOADER, JA 1984. Prediker. Kampen: Kok. (Tekst en toelichting.)

MÜLLER, H-P 1986. Theonome Skepsis und Lebensfreude . BZ 30, 1-19.

MURPHY, RE 1955. The pensées of Qoheleth. $C B Q 17,304-314$.

MURPHY, RE 1981. Wisdom literature. Grand Rapids: Eerdmans. (Forms of the Old Testament Literature.)

MURPHY, RE 1982. Qohelet interpreted: The bearing of the past on the present. VT 32, 331-337.

NICHOLS, FW 1984. Samuel Beckett and Ecclesiastes on the borders of belief. Encounter 45: 11-21.

OBERHOLZER, JP 1972. Die boek Prediker - 'n smartkreet om die gevalle mens. Pretoria: Universiteit van Pretoria. (Kerklike rede by geleentheid van die aanvaarding van die benoeming as Professor in en Hoof van die Departement Ou-Testamentiewe wetenskap, Afdeling A, Universiteit van Pretoria.)

PETER, CB 1980. In defence of existence: A comparison between Ecclesiastes and Albert Camus. Bangalore ThF 12: 26-43.

PFEIFFER, E 1965. Die Gottesfurcht im Buche Kohelet, in Reventlow, HG (Hrsg), Gottes Wort und Gottes Land: Hans-Wilhelm Hertzberg zum 70. Geburtstag. Grttingen: Vandenhoeck.

ROUSSEAU, F 1981. Structure de Qohelet I 4-11 et plan du livre. VT 31, 200-217.

SALTERS, RB 1975. Qoheleth and the canon. ET 86, 339-342.

SCOBIE, CHH 1984. The place of wisdom in biblical theology. BTB 14, 43-48.

WALSH, JT 1982. Despair as a theological virtue in the spirituality of Ecclesiastes. BTB 12, 46-49.

WHYBRAY, RN 1980. Two Jewish theologies: Job and Ecclesiastes. Hull: University of Hull.

WHYBRAY, RN 1982. Qoheleth, preacher of joy. JSOT 23, 87-98.

ZIMMERLI, W 1962. Prediger. Göttingen: Vandenhoeck. (ATD.)

ZIMMERLI, W 1974. Das Buch Kohelet - Traktat oder Sentenzensammlung? VT 24, 221-230. 
Die relevansic van die boel Prediter

ZIMMERLI,W 1983. 'Unveränderbare Welt' oder 'Gott ist Gott'?, in Geyer, H-G, Schmidt, JM, Schneider, W \& Weinrich, M (Hrsg), 'Wenn nicht jetzt, wann dann ?': Aufsätze fur Hans-Joachim Kraus zum 65. Geburtstag. Neukirchen : Neukirchener Verlag. 